\title{
Study of a Green House Gas Induced Effects on Transfer Factor of Micronutrients in a Nature Reserve
}

\author{
Samwel Boaz Otieno ${ }^{1, ~ *}$, Emanuel Ngumbi ${ }^{2}$, Christine Odhiambo Nyang'aya ${ }^{2}$, Jagi Gakunju ${ }^{2}$ \\ ${ }^{1}$ Department of Community Health, Great Lakes University, Nairobi, Nairobi \\ ${ }^{2}$ Africa Fund for Endangered Wild Life, Nairobi, Kenya
}

Email address:

samwelbotieno@yahoo.com (S. B. Otieno)

*Corresponding author

\section{To cite this article:}

Samwel Boaz Otieno, Emanuel Ngumbi, Christine Odhiambo Nyang'aya, Jagi Gakunju. Study of a Green House Gas Induced Effects on Transfer Factor of Micronutrients in a Nature Reserve. American Journal of Environmental Protection. Vol. 10, No. 1, 2021 , pp. 30-36. doi: 10.11648/j.ajep.20211001.14

Received: November 24, 2020; Accepted: December 7, 2020; Published: March 17, 2021

\begin{abstract}
Increasing Carbon dioxide in atmosphere affects nutrition due to carbon nutrient penalty or carbon fertilization. Per capita consumption of micronutrients get affected, leading to silent hunger. This study looks at the effect of the greenhouse gasses especially carbon dioxide on micronutrient up take by vegetation and on soil as proxy-indicator of effects in food chain. Fifty soil samples 250 grams each and fourty vegetation samples 100 grams each were taken in georeferenced sites in AFEW in Langata Ecosystem, along a predetermined transects. The samples were put in Ziplocs and transported to Kabete Laboratories and analyzed by Inductively Coupled Plasma Atomic Emission Spectrometry Optima 8000, Perkin Elmer. Micronutrients levels in soil were compared with those in vegetation as away asses possible effects of carbon dioxide on uptake of the micronutrients by vegetation. The micronutrients were measured in $\mathrm{mg} / \mathrm{gm}$. The results show that levels of most of the micronutrients in soil and vegetation shoots varied. No Zinc was detected both in soil and vegetation in all transects. The level of all micronutrients varied between the soil and vegetation but generally much lower in vegetation. The transfer factor (TF) of sodium, magnesium, mercury and Lead were $>1$, Zinc, Aluminium, Copper, and Cobalt were $<1$ suggesting possible GHG effect. It can be concluded that the Transfer Factor in Aluminium, Zinc, Magnesium, Cobalt and cupper in vegetation is below 1 possibly due to effect of Carbon Dioxide.
\end{abstract}

Keywords: Carbondioxide, Micronutrients, Transfer Factor, Vegetation, Soil

\section{Introduction}

The effects of carbon nutrient penalty or carbon dioxide fertilization will lead to decrease of protein, iron, and zinc [7] Increased carbon dioxide has always been found to decrease the concentration of key micronutrients and macronutrients in important crops. Earlier studies have found that increases in carbon dioxide (carbon nutrient penalty) leads to increased carbon and other micronutrients containing carbon like vitamin $\mathrm{C}$ in fruits, but decrease in all other elements, protein, zinc, iron and magnesium, potassium. Potential effects have been examined with nitrogen, iron, zinc, acting as proxy. Increased carbon nutrient penalty in atmosphere in C3 crops has been observed to increase concentration of carbohydrates but decreased proteins. These include rice, wheat, potatoes and some $\mathrm{C} 4$ crops like maize, sugar cane leading to decreased edible tissue [5].

\section{Green House Gasses in the Environment}

Greenhouse gases are affecting quality and quantity of our food and feeds in several ways [7], first through anthropogenic, climate changes which decrease yields of major cereals and biomass in some regions. Second increased temperature, changes, changes in precipitation, patterns and more frequent heat waves, floods drought decrease yields [1, 7]. 
Increased Carbon dioxide also leads to increased photosynthesis in some plants, but at but at expense of quality as carbohydrates increases at the expense of other nutrients [7].

Green House Gasses (GHG) emission in Kenya is estimated to have increased by 17.2 Metric tonnes $\left(\mathrm{MtCO}_{2}\right)$ per year from 1990 to 2010 [16]. In total Kenya is estimated to produce $60.2 \mathrm{MtCO}_{2} \mathrm{e}$ by 2013 which comprises $0.13 \%$ of total world production and $1.38 \mathrm{MtCO}_{2} \mathrm{e}$. per capita. It is also estimated that there $24.07 \mathrm{Mt} \mathrm{CO}_{2} \mathrm{e}$ from 1990 to 2013 [16].

In Kenya annual change of $\mathrm{CO}_{2}$ production is estimated to increase at $2.6 \%$ per annum, with a variation in each sector. Agriculture influences global production due to related direct and indirect emissions from $\mathrm{C}$ and $\mathrm{N}$ systems [20]. It is estimated that the arable land globally is 15 million $\mathrm{km}^{2}$ [14]. Land use Change by de-forestation (LUCF) lead to increase land surface under cultivation therefore contribute significantly to increase $\mathrm{CO}_{2}$ emissions due to release of sequestered carbon [19].

Agriculture (2.6\%), energy (2.6\%), IP (6.3\%) and waste (2.6\%). Agriculture emission increased by $13.53 \mathrm{Mt}^{\mathrm{CO}_{2}}$ from 1990 to 2013 the main increase include enteric fermentation (56\%) and, manure left in pastures $(37 \%)$. The enteric fermentation is determined by type of livestock and livestock nutrition [17].

In Energy sector emission increased by $8.16 \mathrm{MtCO}_{2}$ e from 2009 to 2013 this is driven mainly by reliance on Motor main mode of transport (SNC., 2014). Electricity and thermal production constituted 26\%, and other fuel [16], and combustion about $25 \%$. Transport is dominated by road transport, which is significant and growing contributor to GHG in Kenya. The number of vehicles have tripled from 600,000 to 2.2 million [15].

Kenya's electricity production is from a variety of sources which include hydroelectricity $(44 \%)$, oil $(31 \%)$ geothermal $(23 \%)$ and biofuels $(2 \%)$. It estimated that this contributed

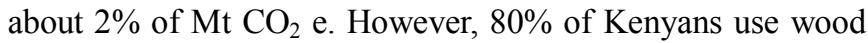
biomass and charcoal [15]. It is estimated that by 2018 Kenya emission per capita was 0.14 Metric Tones $\mathrm{CO}_{2}$, and increasing at $3.0 \%$.

\section{Effect of Atmospheric Carbon Dioxide on Nutrition (Carbon Nutrition Penalty)}

Globally 82 million $\mathrm{p}$ are food insecure with about $22 \%$ of the children or 151 million being stunted and 7.5 million being wasted [17].

Several studies using Nitrogen (protein), zinc, and iron as proxy indicators, show reduction of quality of foods due to Carbon dioxide fertilization by between $2.5 \%-41 \%$. $[30,3]$, L leading to increase in malnutrition related diseases

It is estimated that by the end of the century atmospheric carbon will reach 570micro $\mathrm{mol}^{-1}$ [4]. Under field conditions elevated levels of carbon has a significant reduction in protein $(-10.3 \%)$, Zinc $(-5.1 \%)$ and Iron of $(-8 \%)$ due to increased $\mathrm{CO}_{2}$ concentration in environment [11].

Similarly, vitamins $\mathrm{B}_{1}$ (thiamine), $\mathrm{B}_{2}$ (riboflavin), $\mathrm{B}_{5}$ (pantothenic acid), and $\mathrm{B}_{9}$-(folate) all nitrogen content were found to be significantly reduced by increase of $\mathrm{CO}_{2}$ in the air [11]. The significance of reduction of vitamins is due to $\mathrm{CO}_{2}$ induced changes in Nitrogen content. Under increased concentration of atmospheric $\mathrm{CO}_{2}$ nonleguminous plants increase synthesis of carbohydrates, decrease protein content, and alter proportion of major micronutrients [13].

Induced change of Carbon Dioxide concentrations of micronutrients is estimated to lead to 125.8 million disability adjusted life years globally [3, 4] estimates show that 600 million people could become affected

The effects of Carbon Dioxide concentration will get magnified due to effects on livestock which produces $15 \%$ of global protein. Earlier studies [6] has shown that cattle are increasingly becoming protein stressed due to increased carbon dioxide leading to low growth rates. Replacement of livestock protein costs due to decreased proteins provision is prohibitive.

\section{Effect of Increased Carbon Dioxide on Soil Micronutrients (Carbon Fertilization)}

\subsection{Factors Affecting Production of Carbon Dioxide}

Soil humidity is one of the single most important factors affecting soil GHG emissions, since it controls microbes activity [19]. Water Filled Pores (WFP) in soil affect soil oxygen concentration and hence the microbes activity. Higher $\mathrm{CO}_{2}$ emissions occur in fine textured soils [18], as this favours Carbon/Nitrogen balance in soil. Precipitation following drought conditions leads to Carbon Dioxide fluxesBirch Effect [(Birch., 1958) this dissipates in a few hours with continued precipitation [21]. This is because of availability of decomposable materials in soil at the beginning of the rains.

Temperature explains variation in GHG emissions [9]. It is described by temperature sensitivity factor $\mathrm{Q}_{10}$, which expresses rate of change in biological and chemical system by change of $10^{\circ} \mathrm{C}$.[9]. It ranges from 1.3 to 3.3 and increases with soil depth. Under cold conditions carbon emission is considered as zero. During warming of the environment additional nutrients are released for microbial activity [22] hence increase of emission.

Vegetation and type influences soil respiration [18]. Highest respiration is maximum among younger vegetation stands [10] and decreased with stand age. High biodiversity of vegetation including leguminous tress increases sequestration potential of carbon [30]. Elevated carbon dioxide in soil can be increased by increased atmospheric carbon dioxide concentration [23]. 


\subsection{Effects of Carbon Dioxide Induced pH Change on Nutrient Availability to Vegetation}

As shown in figure 1 Carbon dioxide from both atmosphere and microorganism activity in soil reacts with water to form carbonic acid [8]. The carbonic acid further reacts with ions (in clay and humic micelle) of insoluble minerals present in soil to form soluble bicarbonates which leaches when it rains leading to decreased $\mathrm{pH}$ [8]. The soil gradually becomes acidic in humid regions which increase with drying of the soil micelle. $\mathrm{Ca}+4 \mathrm{H}_{2} \mathrm{O}$-------- $\mathrm{Ca}\left(\mathrm{HCO}_{3}\right)_{2}$

Soil $\mathrm{pH}$ is an important factor for plant growth since it affects nutrient availability, toxicity and protoplasm of plant roots cells [12]. It also affects the soil micro-organisms which are necessary for plant nutrition (Nicol et al., 2008). Most minerals are available in a narrow $\mathrm{pH}$ of 6.5 to 7.5 declining in either direction [12]. Soil pH also affects pesticides and other chemicals added in soil [28]. Further the diversity of plants are affected in low $\mathrm{pH}$ due unavailability of certain micronutrients including $\mathrm{Ca}, \mathrm{Mg}, \mathrm{K}$, and $\mathrm{PO}_{4}$ [29], [8]. Nitrates are converted into nitrites which accumulate and becomes toxic under such circumstances. Similarly, certain ions increase and become toxic in acidic soils [31], these include $\mathrm{Fe}^{++}, \mathrm{Al}^{3+}, \mathrm{Cu}^{2+}, \mathrm{Mn}^{2+}$. Acidic soils also tend to increase CEC leading to leaching of micronutrients which cause deficiency [12]. Alkaline soils tend to be unfavorable to plant growth in soils with deficiency of iron, manganese, and phosphate.

\subsection{Micronutrient Uptake and Accumulation and the Transfer Factor}

Bioavailability of micronutrients to plants in soil is due to a combination of biophysical factors [27]. Soil $\mathrm{pH}$ is one of the key factors in soil which affects other factors like CEC and, Eh [26] The concentration of micronutrients in plant depends on parts of plant, age, tissues and species [25] with higher concentration being in roots and leaves. Uptake and Transmission of micronutrients is determined using a coefficient, Transfer Factor-TF [27]. TF is determined by ratio of concentration of micronutrients in soil compared to the concentration in plant dry tissues (leaves, roots, stem). The Lower values indicate poor absorption which could be due to biophysical conditions [26] which affects speciation and mobility of micronutrients. Higher TF is controlled by capacity of plant to absorb, and eliminate toxic elements and ability to adapt to normal conditions [27]. Different parts of plants accumulate the micronutrients differently, highest accumulation being in roots and leaves.

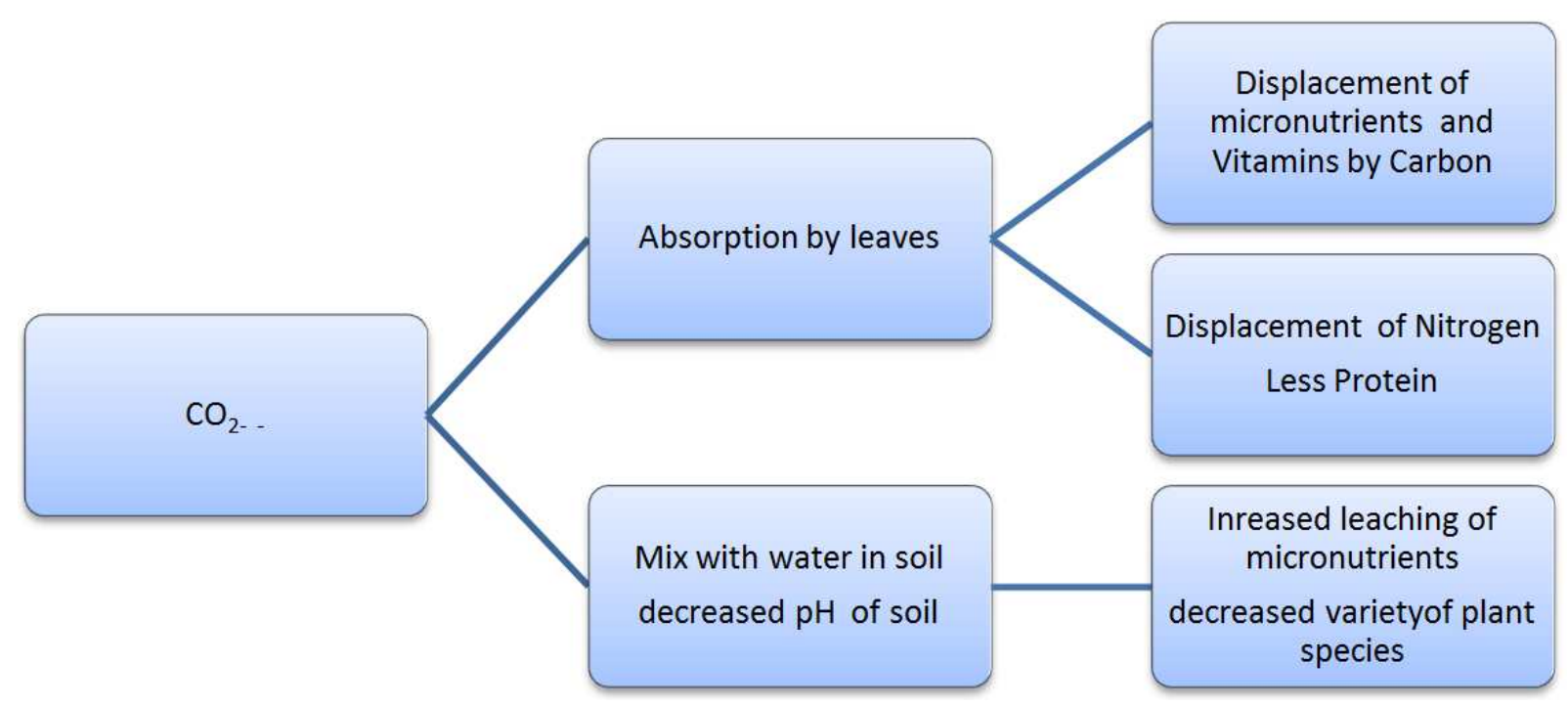

Figure 1. Effect of $\mathrm{CO}_{2}$ on micronutrient intake.

\section{Materials and Methods}

In this study we have analyzed nutrient availability in soils and levels of the same micronutrients in the vegetation in scenario of $\mathrm{CO}_{2}$ level in 2018 in Kenya. To quantify the pathway a transfer factor is used in (Figure 4) a comparison is made between micronutrients in the soils and the levels of content in vegetation leaves at the study site. This site was chosen because of it's proximity to Nairobi industrial area, Kajiado with large number of cattle with enteric fermentation, and busy roads with large number of mot or vehicles. All these activities are known to be responsible for largest quantity of carbon dioxide in Kenya.

\subsection{Soil Sampling}

Sub-Surface soil samples were collected from the Giraffe Centre Nature reserve. Soil samples were collected by Soil Augur at depth of 25 centimetres. Composite samples were made in a bucket and from each a sample of 250 grams was taken. At the same time shoots from vegetation was harvested from the site according to sampling frame indicated below:- 
Table 1. Soil and Vegetation shoots sampling frame work.

\begin{tabular}{|c|c|c|c|c|c|c|c|c|c|}
\hline Batch & Soil & $\mathrm{n} / \mathrm{s}$ & Vegetation & $\mathbf{n} / \mathbf{s}$ & Latitude & Longitude & Altitude & Qt (s) & Qt (v) \\
\hline \multirow[t]{10}{*}{2} & S01 & 1 & V01 & 1 & -1.37726 & 36.74647 & 1771.484863 & $250 \mathrm{gm}$ & $100 \mathrm{gm}$ \\
\hline & S02 & 1 & V02 & 1 & -1.37726 & 36.74647 & 1771.484863 & $250 \mathrm{gm}$ & $100 \mathrm{gm}$ \\
\hline & S03 & 1 & V03 & 1 & -1.37683 & 36.74681 & 1771.017212 & $250 \mathrm{gm}$ & $100 \mathrm{gm}$ \\
\hline & S04 & 1 & V04 & 1 & -1.37683 & 36.74681 & 1771.017212 & $250 \mathrm{gm}$ & $100 \mathrm{gm}$ \\
\hline & S05 & 1 & V05 & 1 & -1.37623 & 36.74719 & 1770.080811 & $250 \mathrm{gm}$ & $100 \mathrm{gm}$ \\
\hline & S06 & 1 & V06 & 1 & -1.37623 & 36.74719 & 1770.080811 & $250 \mathrm{~m}$ & $100 \mathrm{gm}$ \\
\hline & S07 & 1 & V07 & 1 & -1.3761 & -36.7475 & 1765.062012 & $250 \mathrm{gm}$ & $100 \mathrm{gm}$ \\
\hline & S08 & 1 & V08 & 1 & -1.3761 & 36.7475 & 1765.062012 & $250 \mathrm{gm}$ & $100 \mathrm{gm}$ \\
\hline & S09 & 1 & V09 & 1 & -1.37583 & 36.74777 & 1758.450562 & $250 \mathrm{gm}$ & $100 \mathrm{gm}$ \\
\hline & $\mathrm{S} 10$ & 1 & V10 & 1 & -1.37583 & 36.74777 & 1758.450562 & $250 \mathrm{gm}$ & $100 \mathrm{gm}$ \\
\hline \multicolumn{10}{|l|}{ Batch } \\
\hline \multirow[t]{10}{*}{3} & SO1 & 1 & VO1 & 1 & -1.37551 & 36.74789 & 1760.525024 & $250 \mathrm{gm}$ & $100 \mathrm{gm}$ \\
\hline & $\mathrm{SO} 2$ & 1 & VO2 & 1 & -1.37551 & 36.74789 & 1760.525024 & $250 \mathrm{gm}$ & $100 \mathrm{~m}$ \\
\hline & $\mathrm{SO} 3$ & 1 & VO3 & 1 & -1.37498 & 36.74813 & 1768.836548 & $250 \mathrm{gm}$ & $100 \mathrm{gm}$ \\
\hline & $\mathrm{SO} 4$ & 1 & VO4 & 1 & -1.37498 & 36.74813 & 1768.836548 & $250 \mathrm{gm}$ & $100 \mathrm{gm}$ \\
\hline & $\mathrm{SO} 5$ & 1 & VO5 & 1 & -1.37489 & 36.74845 & 1775.153076 & $250 \mathrm{gm}$ & $100 \mathrm{gm}$ \\
\hline & SO6 & 1 & VO6 & 1 & -1.37489 & 36.74845 & 1775.153076 & $250 \mathrm{gm}$ & $100 \mathrm{gm}$ \\
\hline & $\mathrm{SO} 7$ & 1 & VO7 & 1 & -1.37493 & 36.748883 & 1781.917725 & $250 \mathrm{gm}$ & $100 \mathrm{gm}$ \\
\hline & $\mathrm{SO} 8$ & 1 & VO8 & 1 & -1.37493 & 36.748883 & 1781.917725 & $250 \mathrm{gm}$ & $100 \mathrm{gm}$ \\
\hline & SO9 & 1 & VO9 & 1 & -1.37552 & 36.7492 & 1785.673096 & $250 \mathrm{gm}$ & $100 \mathrm{gm}$ \\
\hline & $\mathrm{S} 10$ & 1 & $\mathrm{~V} 10$ & 1 & -1.37552 & 36.7492 & 1785.673096 & $250 \mathrm{gm}$ & $100 \mathrm{gm}$ \\
\hline
\end{tabular}

\subsection{Laboratory Analysis of Samples}

The samples were put in tight Zip Locks and transported to the chemistry lab at Kabete at room temperature for analysis. The analysis was done according method suggested by Zhu et al., 2019.

The samples were homogenized into fine powder using mixer grinder, sifted through a sieve and then dried to constant weight at $70^{\circ} \mathrm{C}$. About $\mathrm{O} .25 \mathrm{O}$ grams sample was added to graphite tube for digestion, $0.2 \mathrm{ml}$ of pure deionized water was added, followed by $8 \mathrm{ml}$ of $\mathrm{HNO}_{3}$ and digested for $24 \mathrm{hrs}$, an additional $2 \mathrm{ml}$ of $\mathrm{HClO}_{4}$ was then added. Digestion temperature was regulated until clear color was obtained. Finally, Deionized water was added to increased remaining solution to $50 \mathrm{ml}$. Inductively Coupled Plasma (ICP) Atomic Emission Spectrometry (AES) Optima 8000 , Perkin Elmer was used to determine various ions.

\subsection{Determination of Micronutrients Transfer Factor}

Assessments of absorption of micronutrients by plants was done using Transfer Factor (TF). This was calculated as ratio of micronutrients in soil compared to the levels in dry matter of leaves. The TF reflects uptake of micronutrients by plants [24]. The higher the value $(>1)$ indicates higher uptake. Most plants accumulate the micronutrients in leaves, hence the assessments.

Transfer Factor $(\mathrm{TF})=$ Cplant/Csoil. (Cplant is Conc.in plant in $\mathrm{mg} / \mathrm{gm}$, Csoil is conc.in soil in $\mathrm{mg} / \mathrm{gm}$ )

\section{Results and Discussion}

\subsection{Uptake of Micronutrients by Vegetation}

Samples were taken along co-ordinates and batches along transects, analysis $(\mathrm{mg} / \mathrm{gm})$ indicated, that several micronutrients of importance to nutrition were found to be available in the soil and vegetation shoots. Sodium, Magnesium, Cobalt, Aluminum and toxic ones, Lead and Mercury were found in soil in varying quantities. These micronutrients were considered as proxy indicator of availability of micronutrients in vegetation.

Micronutrient Levels in soil $\mathrm{mg} / \mathrm{gm}$

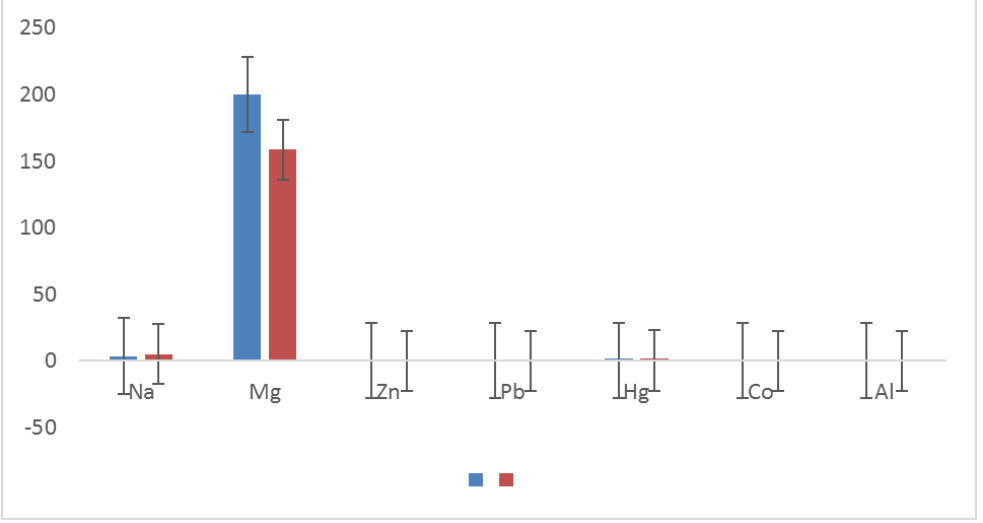

Figure 2. Average micronutrient levels in soil in $\mathrm{mg} / \mathrm{gm}$ in TS 1 and TS 2. 
As in figure 2 in vegetation shoots Zinc was not detected in soil samples taken. The soil Sodium quantities average quantities in soil was $3.5221 \mathrm{mg}_{\text {gram }}{ }^{-1}$, Magnesium was $55.1572 \mathrm{mg}$ gram $^{-1}$, Aluminium $1144.4618 \mathrm{~m} \mathrm{gm}^{-1}$, and Cupper $0.3783 \mathrm{mg} \mathrm{gm}^{-1}$ the others varied in levels.

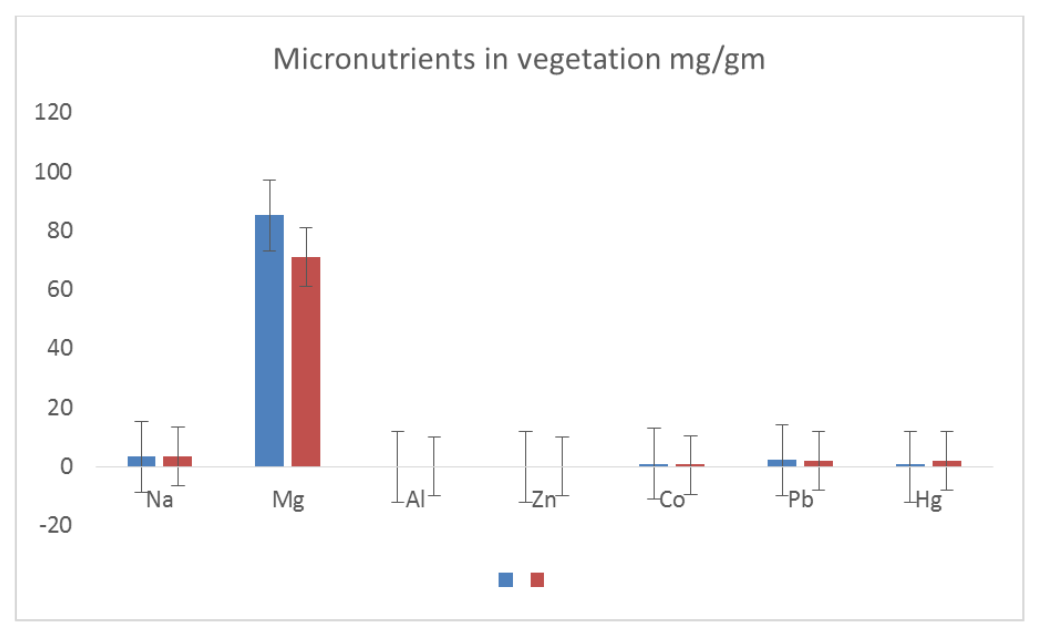

Figure 3. Average micronutrient level in vegetation (TS 1 and TS 2).

As shown in figure 3, The average Lead level was $2.3511 \mathrm{mg} \mathrm{gm}^{-1}$ in vegetation., average Mercury level was $0.0144 \mathrm{mg}$ gram $^{-1}$ in vegetation. The average level of Sodium was $3.5256 \mathrm{mg} \mathrm{gm}{ }^{-1}$, Magnesium at $117.2321 \mathrm{mg} \mathrm{gm}^{-1}$, Aluminium at $10.6591 \mathrm{mg} \mathrm{gm}^{-1}, .197 \mathrm{mg} \mathrm{gm}^{-1}$ in vegetation. All other micronutrients varied.

\subsection{Effect of GHG on Accumulation of Micronutrient by Vegetation Shoot}

As shown in table 1 the proxy effects of micronutrients effects of GHG was estimated by TF of various micronutrients in shoot of vegetation at the reserve. Lead had the highest TF while other micronutrients had varied values.

Table 2. Concentration of Micronutrients in Soil and Vegetation and Transfer Factor.

\begin{tabular}{llllllll}
\hline & Na & Mg & Al & Cu & Co & Zn & Hg \\
\cline { 2 - 7 } & \multicolumn{1}{l}{ Average Concentration in $\mathbf{~ m g / g m ~ a n d ~ T F ~}$} & & & & \\
\hline Vegetation & 3.5256 & 117.2321 & 106.5911 & 0.2303 & 0.0197 & 0 & 0.0144 \\
Soil & 3.5221 & 55.1572 & 11444618 & 0.3783 & 0.8824 & 0 & 2.3511 \\
TF & 1.0000 & 2.1250 & 0.0090 & 0.6090 & 0.0223 & 0 & 0.1821 \\
\hline
\end{tabular}

The results show that generally the TF was less than $1(<1)$ in Aluminium (0.009), Cobalt (0.0223), Cupper (0.609) and Zinc (0). This phenomenon could be due to several factors, Beach et al., 2019 reported reduced Zinc in vegetation shoots due to carbon fertilization. Displacement of micronutrients by increased carbon dioxide (carbon nutrient penalty) in air from the leaves have also been reported [2], our observation here tend to suggest that, this could be the case with Cobalt and $\mathrm{Al}$ and $\mathrm{Cu}$. Swaggata et al., 2019, reported that Aluminium ions react with water which liberate hydrogen ions thereby increasing soil acidity. This could have further affected speciation and mobility of some micronutrients like Cobalt and Zinc leading to leaching in soil or low uptake by plants.

There was variation of other micronutrients level between soil and vegetation shoots. Cobalt was found in the soil but was not detected in the vegetation shoots. Other micronutrients were in soil but were in varied levels in vegetation. This phenomenon could be due to several factors, Beach et al., 2019 reported reduced Zinc in in vegetation shoots due to carbon fertilization. Displacement of micronutrients by increased carbon dioxide (carbon nutrient penalty) in air from the leaves have also been reported [2], our observation here tend to suggest that, this could be the case with Cobalt, Aluminium, and Cupper. [8], reported that Aluminum ions react with water which liberate hydrogen ions thereby increasing soil acidity. This could have further affected speciation and mobility of micronutrients like Cobalt, Aluminum and Copper and Zinc leading to leaching in soil or low intake by plants.

The mobility of a micronutrient species from the soil into plant roots is referred to as transfer factor (TF). Several factors are involved in the root uptake of the micronutrients (less the levels of absorption by leaves from atmosphere deposits). Higher transfer factor indicate higher accumulation of micronutrient.

In this study $\mathrm{TF}$ of the micronutrients varied. Some micronutrients had higher $(>1) \mathrm{TF}(\mathrm{Pb}, \mathrm{Mg}, \mathrm{Na})$ while others had low level $(<1)$ of TF $(\mathrm{Zn}, \mathrm{Cu}, \mathrm{Mo}$,) while it was $>1$ in $\mathrm{Na}(1.000) \mathrm{Mg}$ (2.125), $\mathrm{Hg}$ (1.273) and Lead (13.056) in the order $\mathrm{Zn}<\mathrm{Al}<\mathrm{Co}<\mathrm{Cu}<\mathrm{Na}<\mathrm{Hg}<\mathrm{Mg}<\mathrm{Pb}$.

The concentration of micronutrients in soil depend on 
biochemical characteristics of the soil [26] and proximity from the contaminating source [27]. Uptake and accumulation of micronutrients by plants (TF) varies with micronutrients type, plant species, concentration of micronutrient, biochemical characteristics of the soil [26] and alternative absorption from atmosphere [28]. Soil $\mathrm{pH}$ which is determined by a greenhouse gas $-\mathrm{CO}_{2}$ particularly have very great effect on speciation and mobility of micronutrients. The results in this study tend to agree with other researches [27] which suggests that foliar of plants could be a better way to measure Transfer Factor of micronutrients. Plant micronutrient contamination in some cases arises from atmospheric particle accumulation through leaves hence proximity to a road or the river in AFEW Nature reserve could be playing a role in contamination with toxic micronutrients observed.

$\mathrm{Pb}$ had high $\mathrm{TF}$ of 13.056, which is higher compared to other observations [27]

Given that plants accumulate micronutrients by foliar and by roots it is possible that the road near the reserve or the river near the site of the study could have contributed to higher lead TF. It also shows that the vegetation in the Reserve could be accumulators hence indicators of the presence of lead in environment. Other micronutrients with higher TF included $\mathrm{Na}$ (1.000), $\mathrm{Mg}$ (2.00), $\mathrm{Hg}$ (1.25).

\section{Recommendation}

Lead, and Mercury are toxic when consumed. This study suggests higher TF of these two micronutrients in the Reserve. which could be a risk factor to animals consuming the vegetation these micronutrient and humans growing vegetables near the reserve. Further analysis need to be done on stream and dust near the road to determine whether foliar uptake could be a contributing source of these toxic micronutrient. The $\mathrm{TF}$ for $\mathrm{Al}, \mathrm{Co}$, and $\mathrm{Cu}$ were $<1$, further study is needed to determine role of carbon dioxide in affecting the levels of these micronutrients in the reserve.

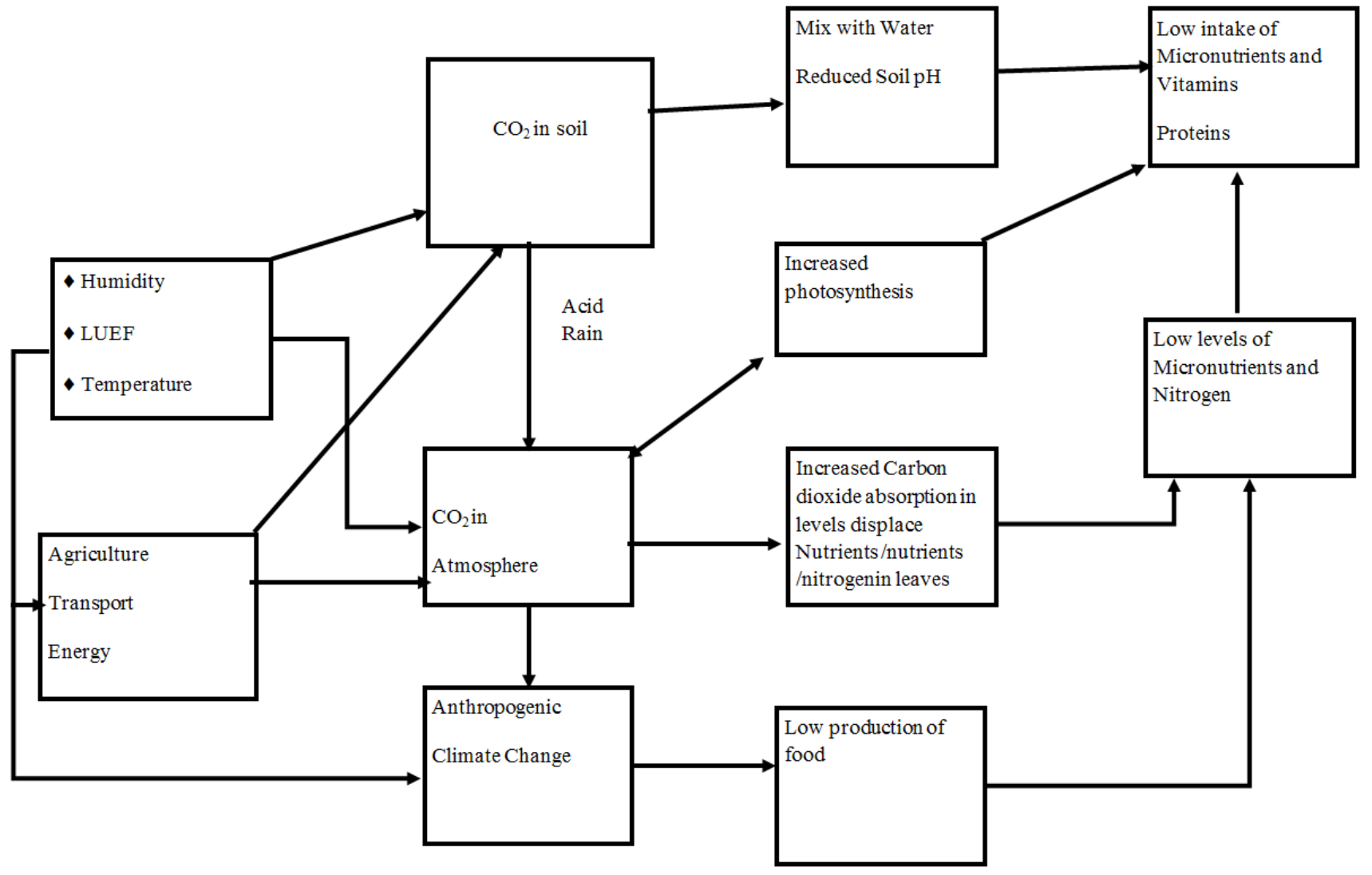

Figure 4. Pathway of GHG effect on TF of Micronutrient.

\section{References}

[1] Porte JR, Xie L, Challinator AJ (2014), Food Security and Food systems, In, Field CB, Barros VR, Dkken DJ (2014) Eds, Climate Change, Impacts Adaptation, and Vulnerability, Part A, global and Sctors aspects. Contribution of Working Group II to the fifth assessment report of the intergovernmental panel on climate change, Cambridge and New Yolk NY Cambridge University Press., 2014: 485-533.
[2] Loladze I, Hidden (2014) shift of ionome of plants exposed to elevated $\mathrm{CO}_{2}$ depletes minerals at the base of human nutrtion. elife; 3 ; $\mathrm{e} 02245$.

[3] Myers SS, Zanobetti A, Kloog I (2014) increasing $\mathrm{CO}_{2}$ threatens human nutrtrition, Nature 2014, 510; 139-42.

[4] Zhu C, Kobayasi K, Loladze (2018). Carbon Dioxide levels will alter protein, micronutrients, and vitaminscontent of rice grains with potential health consequences for poorest rice dependent countries, Science Advances, 4, eaaq1012. 
[5] Beach RH, Sulser TB, Crimmins A (2019), Combinig the effects the effects of inceased atmospheric carbon dioxide on protein, iron, and zinc availability and projected climate change on global diets, a modelling study, Lancet Planet Health 2019, 3; e307-17.

[6] Craine JM, Elmore A, Angerer JP, (2017) Longterm Declines in nutritional quality for North America cattle, Environment Research 12; 0444019.

[7] Kristie L, Irakli Loladze (2019) Elevated atmospheric $\mathrm{CO}_{2}$ concentrations and climate change will affect our foods quality and quantity, Lancet planetary health; 3: e 283-284.

[8] Swaggat P., (2019) $\mathrm{pH}$ of Soil and Factors affecting it: properties $/ \mathrm{H}$-of Soil and factors affecting it - it 3622: Soil Management india: 1-8.

[9] Berglund O, Berglund K, Klemedtstone (2008) A lysimeter study on the effect of temperature on $\mathrm{CO}_{2}$ emission from cultivated peat soils, Elsiever; 154, 2-4, 211-218.

[10] Saiz G Michael I. Bird Tomas Domingues Franziska SchrodtMichael Schwarz Ted R. Feldpausch Elmar Veenendaal Gloria Djagbletey (2015) Variation in soil carbon stocks and their determinants across a precipitation gradient in West Africa.

[11] Tijsre T, Sponseller R, Laudon H,(2019) Contrasting responses in dissolved organic carbon to extreme climate events from adjacent boreal landscapes in Northern Sweden. Environmental Research Letters; 14: 1-9.

[12] Soti G, P, Krish J, Koptur S, Volin JC (2015) Effect of Soil pH on growth, nutrient uptake and mycorrhization colonization in exotic invasive lygodium microphyllum, Plant Ecology 216, 989-999.

[13] Wiebe K, Lotze-Campen H., Sands R., Tabezau D., (2050 Climate change impacts in Agriculture in 2050 under arrange of plausible spcioeconomic and emmissions scenerios Environment Research Letter 10: 8.

[14] FAO (2011) Global food losses and food waste, extent cause and and prevention, Rome 2011.

[15] IPCC 2006 Climate change 2014, mitigation of climate change Cambridge university press.

[16] Colenbrander Sarah, Andrew H Sudmant, Andy Gouldson, Igor Reis de Albuquerque, Faye McAnulla, Ynara Oliviera de Sousa (2017) The economics of climate mitigation: exploring the relative significance of the incentives for and barriers to low-carbon investment in urban areas: Urbanisation. 2 (1) 1.

[17] Food and Agriculture Organization of the United Nations Statistics Division (FAOSTAT, 2018). Brazil, Emissions Land use total and Emissions - Agriculture total, viewed on August 19, 2018.- 43 .

[18] Dilustro J J, Day F P, Drake B G (2001) Effects of elevated atmospheric $\mathrm{CO}_{2}$ on root decomposition in a scrub oak ecosystem, Global Change, 581-589.
[19] Oertel C, Jörg Matschullat, Kamal Zurbaa, Frank Zimmermanna, Stefan Erasmi (2016) Greenhouse gas emissions from soils-A review: Elsiever Chemie der Erde 76: $327-352$.

[20] Wang, Y. Y., Hu, C. S., Ming, H., Zhang, Y. M., Li, X. X., Dong, W. X., Oenema, O., 2013b. Concentration profiles of $\mathrm{CH}_{4} \quad \mathrm{CO}_{2}$ and $\mathrm{N}_{2} \mathrm{O}$ in soils of a wheat-maize rotation ecosystem in North China Plain, measured weekly over a whole year. Agric. Ecosyst. Environ. 164, 260-272. 352.

[21] Sponseller, R. A., 2007. Precipitation pulses and soil $\mathrm{CO}_{2}$ flux in a Sonoran Desert ecosystem. Glob. Change Biol. 13, 426436.

[22] Christiansen, J. R., Korhonen, J. F. J., Juszczak, R., Giebels, M., Pihlatie, M., 2011. Assessing the effects of chamber placement, manual sampling and headspace mixing on $\mathrm{CH}_{4}$ fluxes in a laboratory experiment. Plant Soil 343, 171-185.

[23] Dorodnicov M, Blagodatskaya E, Kuzyako Y Elevated atmospheric $\mathrm{CO}_{2}$ increases microbial growth rates in soil: results of three $\mathrm{CO}_{2}$ enrichment experiments; Global Change Biology 16: 2 836-848.

[24] Rangnekar, S. S., Sahu, S. K., Pandit, G. G. and Gaikwad, V. B. (2013). Accumulation and Translocation of Nickel and Cobalt in Nutritionally important Indian vegetables grown in artificially contaminated soil of Mumbai, India. Research Journal of Agricultural and Forest Sciences 1: 15-21.

[25] Filipović-Trajković, R., Ilić, S. Z. and Šunić, L. (2012). The potential of different plant species for heavy metals accumulation and distribution. The Journal of Food, Agriculture and Environment 10: 959-964.

[26] Otieno S B, Jayne T S, Milu M, (Effects of soil chemical characteristrics in accumulation of Native selenium Zea mays growing areas in Kenya.

[27] Mirecki N, Rukie Agič, Ljubomir Šunić, Lidija Milenković and Zoran S. Ilić (2015). Transfer factor as indicator of heavy metals content in plants Fresenius Environmental Bulletin 24, $11 \mathrm{c}$.

[28] Lu, S., Kong, L., Li, S., Chen, B. Zhang, Y. and Pan, Q. (2014). Accumulation of heavy metals associated with trees planted in Beijing, China. Journal of Food Agriculture and Environment 12: 508-512.

[29] Larcher W (2003) Physiological Ecology: Ecophysiological Stress Physiology of functional groups. 4th Edition, ISBN 3540-4316-6 Springer 1-72.

[30] Fornara A and Tilman D (2008) Plant functional composition influences rates of soil carbon and nitrogen accumulation Journal of Ecology 2008, 96, 314-322.

[31] Kinraide T B, Ryan P R, Kochian LV (1993) Al, Ca, interractions in Aluminium rhizotoxicity: Evaluating the $\mathrm{Ca}$ displace ment hypothesis: Planta, 192: 104-109. 